\title{
MENINGKATKAN KECERDASAN KINESTETIK ANAK MELALUI GERAK TARI HUDOQ DAYAK BAHAU DI TAMAN KANAK - KANAK NEGERI PEMBINA 2 MUARA WAHAU
}

\author{
Nila Sari Yanti ${ }^{1}$, Hanita ${ }^{2}$ \\ PG PAUD Universitas Widya Gama Mahakam Samarinda \\ E-mail: ukhtinilasari@gmail.com, nitahanita87@gmail.com
}

\begin{abstract}
A child is defined as an individual who entering adult phase. When they are getting older, they must master basic competence. In this stage, all potentials they have are developed, including kinesthetic intelligence. In case of students in Pembina 2 Kindergarten Muara Wahau, they showed low kinesthetic intelligence since they looked bored, and did not focus on lesson when doing sport exercise. Kinesthetic intelligence in early age students can be stimulated through dance, since, basically, they like music and dance. Dancing demands balance, body movement coordination, strength, and muscle flexibility. This study applied classroom action research. The research subjects were students of Group B Pembina 2 Kindergarten Muara Wahau. Meanwhile, the aspects being analyzed were students' ability in imitating the movement fast, remembering dance movement, coordinating movement and rhythm, and dancing without help. The data were collected through documentation and direct observation toward the teacher and the students, observing teacher conducting teaching and learning process by implementing Hudoq Dayak Bahau dance. The result shows that, in precycle, the average score was $17,3 \%$, meaning that students had not developed yet. At the first cycle, students achieved $40,98 \%$, meaning that students started to develop. The percentage increased into $97,7 \%$ at second cycle, meaning that students developed very well. Therefore, it can be concluded that teaching with Hudoq dayak bahau dance is effective to improve kinesthetic intelligence, especially for students of group B in Pembina 2 Kindergarten Muara
\end{abstract}


Wahau. It is expected that teachers can apply this method to improve students' kinesthetic intelligence.

\title{
Keywords : Kinesthetic Intellegience, Hudoq Dayak Bahau Dance
}

\begin{abstract}
Abstrak
Definisi anak adalah individu yang memasuki fase dewasa. Ketika usia bertambah tampak sejumlah kemampuan dasar yang dimilikinya. Dalam masa- masa ini, segala potensi kemampuan anak dapat dikembangkan salah satunya kecerdasan kinestetik peserta didik di Taman Kanak-kanak Negeri Pembina 2 Muara Wahau. Dalam hal ini, peserta didik di Taman Kanak-kanak Negeri Pembina 2 Muara Wahau menunjukkan kecerdasan kinestetik yang dibawah rata rata, Hal tersebut terlihat dengan peserta didik terlihat bosan, tidak serius, dan jenuh ketika melakukan gerakan olahraga. Kecerdasan kinestetik anak usia dini dapat distimulasi melalui menari ,karena anak pada dasarnya menyukai music dan tari. Menari menuntut keseimbangan, keselarasan gerak tubuh, kekuatan, dan kelenturan otot. Jenis penelitian adalah Penelitian Tindakan Kelas. Subjek dan Objek penelitian adalah Taman Kanak-kanak Negeri Pembina 2 Muara Wahau di kelompok B. Data pengumpulan diperoleh dengan dokumentasi dan observasi.Hasil penelitian disetiap siklus dapat dilihat sebagai berikut, dilihat dari hasil nilai rata-rata pra siklus diperoleh $17,3 \%$, tergolong Belum Berkembang, pada siklus I meningkat diperoleh rata-rata 40,98\%, tergolong Mulai Berkembang, dan pada siklus II meningkat lagi diperoleh rata-rata $97,7 \%$, tergolong Berkembang Sangat Baik. Dari hasil penelitian pada setiap siklus maka dapat dikatakan bahwa penggunaan metode menari hudoq dayak bahau dapat meningkatkan kecerdasan kinestetik anak di Kelompok B. Berdasarkan hasil penelitian tersebut, makan dapat disimpulkan bahwa dengan menggunakan metode menari hudoq dayak bahau dapat meningkatkan kecerdasan anak di kelompok B Taman Kanakkanak Negeri Pembina 2 Muara Wahau. Dengan pelaksanaan penelitian ini diharapkan sekolah khususnya guru menggunakan metode ini karena metode menari tari hudoq dayak bahau dapat meningkatkan kecerdasan kinestetik anak.
\end{abstract}


Kata Kunci : Meningkatkan Kecerdasan Kinestetik,Tari Hudoq Dayak Bahau

\section{Pendahuluan}

Anak merupakan anugerah dari Allah SWT. Secara umum, definisi anak adalah individu yang belum memasuki masa dewasa. Ketika usia bertambah tampak sejumlah kemampuan dasar yang dimilikinya. Dalam masa-masa ini, segala potensi kemampuan anak dapat dikembangkan secara optimal, tentunya dengan bantuan dari orang - orang yang berada dilingkungan anak-anak tersebut. Pendidikan Anak Usia Dini, yang selanjutnya di singkat PAUD, merupakan suatu upaya pembinaan yang ditujukan kepada anak sejak lahir sampai dengan usia 6 (Enam) tahun yang dilakukan melalui pemberian rangsangan pendidikan untuk membantu pertumbuhan dan perkembangan jasmani dan rohani agar anak memiliki kesiapan dalam memasuki pendidikan lebih lanjut Kemendikbud No. 146:2013(Giri 2013). Pendidikan Anak Usia Dini merupakan salah satu bentuk penyelenggaraan pendidikan yang menitikberatkan pada peletakan dasar ke arah pertumbuhan dan perkembangan fisik (koordinasi motorik halus dan kasar), kecerdasan (daya fikir, daya cipta, kecerdasan emosi, kecerdasan spiritual) sosio emosional (sikap dan perilaku serta agama) bahasa dan komunikasi, sesuai dengan keunikan dan tahap - tahap perkembangan yang dilalui oleh anak usia dini.

Semua anak pada dasarnya adalah cerdas dan memiliki lebih dari satu bakat. Untuk itu anak perlu diberikan pendidikan dan pembelajaran yang sesuai dengan perkembangannya dengan memberi atau menyediakan tempat untuk berekspresi ,berkreasi, berimajinasi, dan menggali semua potensi diri anak. Kecerdasan anak sudah dimiliki sejak lahir hingga dewasa, untuk 
mengembangkan kecerdasan anak harus diberi stimulasi. Kecerdasan sendiri, merupakan cara berfikir seseorang untuk dijadikan modal dalam belajar.

Menurut Gardner (Suyadi 2016), mengatakan bahwa kecerdasan seorang meliputi unsur - unsur kecerdasan matematika logika, kecerdasan bahasa, kecerdasan musikal, kecerdasan visual spasial, kecerdasan naturalis, kecerdasan interpersonal, kecerdasan intrapersonal, dan terakhir adalah kecerdasan kinestetik. Kecerdasan kinestetik adalah kemampuan untuk menggambungkan antara fisik dan pikiran sehingga menghasilkan gerakan yang sempurna. Jika gerak sempurna yang bersumber dari gabungan antara pikiran dan fisik tersebut terlatih dengan baik apapun yang dikerjakan orang tersebut akan berhasil dengan baik bahkan sempurna. Dalam konteks anak-anak, gerak sempurna tersebut lebih mudah dibentuk atau dilatih semenjak ia masih berusia dini karena pada usia ini fisik sedang mengalami pertumbuhan yang baik, disamping perkembangan otaknya yang sedang pesat-pesatnya. Kondisi ini sangat memungkinkan anak usia dini memadukan pikiran dan gerak tubuhnya sehingga menghasilkan gerak-elastis yang sangat sempurna. Bahkan, Mereka dapat melakukan gerakan gerakan akrobat dengan sangat baik dan cepat melebihi orang dewasa.

Sebenarnya, gerak fisik-motorik tersebut masih dalam kendali pusat saraf dalam pikiran anak. Artinya, kecerdasan kinestetik merupakan koordinasi yang baik antara urat saraf (pikiran) dengan organ tubuh yang lain. Keterampilan mengoordinasikan pikiran dan organ tubuh dalam bentuk berbagai gerakan tersebut mampu memperkuat rasa kepercayaan diri pada anak - anak sehingga tertanam dalam hati mereka bahwa dirinya sanggup 
melakukan pekerjaan apapun dengan hasil yang terbaik. Perasaan demikian akan mendorong anak melakukan berbagai aktivitas pembelajaran dengan semangat dan penuh rasa senang.

Menurut Stipek (Sujiono 2010) mengemukakan sebuah penemuan yang mengejutkan. Ia menulis hingga usia enam atau tujuh tahun anak - anak menaruh harapan yang tinggi untuk berhasil, meskipun kinerja pada usaha - usaha yang dilakukan nya hampir selalu buruk. Jika kepercayaan diri mereka telah dibuktikan sendiri melalui keberhasilan demi keberhasilan yang terbaik, daya optimisme dalam meraih keberhasilan semakin menguat. Daya optimisme inilah yang sekarang dikenal dengan sebutan kecerdasan emosional (EQ). Dengan demikian, kecerdasan kinestetik merupakan embrio bagi berkembangnya kecerdasan emosional anak. Oleh karena itu, kecerdasan kinestetik juga bisa disebut sebagai kemampuan untuk menggabungkan antara kinerja pikiran dan kinerja fisik untuk meraih tujuan yang diharapkan.

Kecerdasan kinestetik anak dapat dikembangkan melalui bermain, gerak - lagu (menyanyi), merangkak, kolase, berolahraga, dan menari. Cara tersebut bertujuan merangsang atau menstimulasi kemampuan fisik meliputi menggerakkan seluruh anggota tubuh, kemampuan mengatur keseimbangan tubuh, dan ketangkasan gerak. Pada masa usia dini ini, stimulasi yang paling baik diberikan kepada anak adalah menari. Mengacu pada penelitian yang terdahulu kecerdasan kinestetik bisa ditingkatkan melalui gerak tari tradisional jepen, hal ini di karena kan menari merupakan langkah yang paling tepat dalam memberikan pembelajaran pada anak agar lebih cepat 
mempelajari, menguasai, dan mempraktikkan suatu materi pembelajaran atau setiap sisi kehidupan dan suatu budaya.

Permasalahan yang akan dibahas dalam penelitian ini menyangkut pengembangan kecerdasan kinestetik anak yang ditingkatkan melalui gerak tari Hudoq Dayak Bahau yang merupakan salah satu tari tradisional yang cukup dikenali peserta didik Taman Kanak-Kanak Negeri Pembina 2 Muara Wahau. Dalam hal ini, Peserta didik Taman Kanak-Kanak Negeri Pembina 2 Muara Wahau menunjukkan kecerdasan kinesetetik yang kurang, hal tersebut ditandai dengan Peserta didik Taman Kanak-Kanak Negeri Pembina 2 Muara Wahau terlihat sangat bosan, tidak serius, dan jenuh ketika melakukan gerak olahraga ini terlihat dari peserta didik tidak bergerak ketika di arahkan guru untuk berolahraga, sebagian peserta didik memanjat tiang bendera saat berlangsung nya olah raga dan sebagian lagi berlari bermain tanpa mengikuti arahan gerak olah raga, Namun ketika guru mengenalkan salah satu tarian tradisional yang cukup terkenal dlingkungan tempat tinggal peserta didik yaitu Tari Hudoq Dayak Bahau,para peserta didik terlihat sangat tertarik dan memperhatikan dengan seksama.

Berdasarkan latar belakang di atas peneliti tertarik untuk melakukan penelitian tindakan kelas (PTK) pada anak usia 5-6 tahun di Taman Kanak-Kanak Negeri Pembina 2 Muara Wahau dengan judul "Meningkatkan Kecerdasan Kinestetik Anak Melalui Gerak Tari Hudoq Dayak Bahau Pada Kelompok B di Taman Kanak-Kanak Negeri Pembina 2 Muara Wahau Tahun Pelajaran 2018/2019.

Tujuan penelitian untuk bisa meningkatkan kemampuan kecerdasan kinestetik anak melalui gerak Tari Hudoq Dayak 
Bahau di Kelompok B Taman Kanak-Kanak Negeri Pembina 2 Muara Wahau.

\section{Metode Penelitian}

Penelitian ini menggunakan model Penelitian Tindakan Kelas Dalam konteks pendidikan PTK merupakan tindakan perbaikan guru dalam mengorganisasi pembelajaran dengan menggunakan prosedur perencanaan, pelaksanaan tindakan, melakukan pengamatan, dan refleksi.

Subjek penelitian ini adalah anak kelompok usia 5-6 tahun di Taman Kanak-Kanak Negeri Pembina 2 Muara Wahau dengan jumlah murid 15 orang, anak laki - laki 6 orang dan anak perempuan 9 orang dengan 1 guru kelas dan guru pendamping. Sedangkan objek penelitian ini adalah meningkatkan kecerdasan kinestetik anak melalui gerak tari hudoq dayak bahau pada kelompok B di Taman Kanak-Kanak Negeri Pembina 2 Muara Wahau pada tahun pelajaran 2018/2019.

Pembelajaran dengan metode gerak tari hudoq dayak bahau ini dilaksanakan pada kelompok B di Taman Kanak -Kanak Negeri Pembina 2 Muara Wahau yang dimulai pada bulan Juli 2018 dengan 3 siklus 6 kali pertemuan

Prosedur penelitian Tindakan Kelas terdiri atas:

1. Prasiklus

2. Siklus I

3. Siklus II

Pada tahap ini peneliti melakukan pengumpulan data proses dan hasil belajar, untuk selanjutnya diolah, dianalisis, dan diinterpretasi. Serta menggunakan analisis deskripsi kualitatif 
Kriteria keberhasilan pada penelitian ini ditandai dengan adanya perubahan kearah perbaikan dan untuk keberhasilan penelitian ini apabila hasil kegiatan anak dalam menari tari hudoq dayak bahau terjadi peningkatan mencapai $80 \%$ dari jumlah anak. Kecerdasan kinestetik dengan kriteria Berkembang Sangat Baik (BSB), presentase ketuntasan ini dilakukan untuk mempertegas peningkatan kecerdasan kinestetik anak melalui gerak tari hudoq.

Menurut Arikunto (dalam Aqib 2017) untuk menghitung presentase ketuntasan belajar siswa secara klasikal dihitung dengan rumus:

Ketuntasan Klasikal $=\frac{\text { Esiswa yang tuntas belajar }}{\text { Eseluruh siswa }} \times 100 \%$

Indikator ketuntasan belajar siswa secara klasikal $80 \%$ (sangat baik) dari jumlah siswa dinyatakan tuntas belajar.

\section{Hasil dan Pembahasan}

Hasil penelitian ini menunjukkan pada Pra siklus pertemuan I dan II diperoleh hasil dengan rata - rata diperoleh nilai $17,3 \%$ tergolong belum berkembang, dinyatakan belum berhasil. Hal ini disebabkan oleh guru belum menjelaskan gerak tari Hudoq Dayak Bahau; anak belum terlihat menari dengan benar; waktu belum ditentukan lagi; cara menerangkan media musik dan kostum hudoq masih perlu diperjelas lagi. Hal ini sejalan pada siklus I pertemuan I dan II diperoleh hasil dengan rata - rata di peroleh $40,98 \%$ dengan kategori belum berkembang, dinyatakan belum berhasil hal ini disebabkan oleh perlu memperjelas media musik dan contoh tari hudoq dayak bahau;mengajarkan gerak dasar tari Hudoq Dayak Bahau tetapi anak kurang memperhatikan; dan masih kurang penjelasan guru dan gerakan tari yang sulit dipahami anak. 
Pada siklus II diperoleh hasil jumlah nilai ketuntasan belajar anak memperoleh nilai $97,7 \%$ dinyatakan berhasil dengan katagori berkembang sangat baik. Hal ini disebabkan, dalam menerangkan guru memberikan kebebasan anak dalam memulai tarian dan beraturan;gerakan yang sulit sudah dihafal anak.

Berdasarkan hasil penelitian kecerdasan kinestetik anak dapat ditingkatkan melalui gerak tari. Hal ini sejalan dengan teori yang dikemukakan oleh Campbell dan Dickinson (Suyadi 2016) yang menjelaskan bahwa tujuan materi program dalam kurikulum yang dapat mengembangkan kecerdasan fisik salah satu nya menari. Sujiono (2010) menambahkan bahwa cara menstimulasi kecerdasan fisik pada anak adalah dengan menari, sebab anak -anak pada dasarnya menyukai musik dan tari. Untuk mengasah kecerdasan fisik ini dapat dilakukan dengan mengajak anak untuk menari bersama, karena menari menuntut keseimbangan, keselarasan gerak tubuh,kekuatan, dan kelenturan otot. Sedangkan pengertian dari kecerdasan kinestetik atau fisik sendiri adalah kemampuan untuk secara aktif menggunakan bagian - bagian atau seluruh tubuhnya, hal ini akan dijumpai pada peserta didik yang pandai menari. berdasarkan penelitian yang relevan terdahulu yang dilaksanakan oleh Arbibah (2017) dapat membuktikan bahwa kecerdasan kinestetik dapat ditingkatkan melalui gerak tari. Seni tari sendiri merupakan salah satu warisan budaya indonesia yang harus dikembangkan dan dilestarikan selaras dengan masyarakat yang selalu mengalami perubahan. Menurut Sekarningsih dan Rohayani (dalam Mulyani 2016) pada dasarnya manusia ataupun binatang dapat mengungkapkan gerakan, tidak lepas dari adanya unsur -unsur tenaga, tempat atau ruang. Kemudian, karena gerakan tersebut biasanya saling 
menyambung, maka akan tersusun rangkaian gerak yang berkelanjutan. Jika hal tersebut diteliti lebih mendalam, maka tampak dari peralihan - peralihan gerak tersebut ada sebuah tempo atau waktu sisipannya. Dengan demikian, gerakan atau rangkaian gerakan tersebut adalah akibat dari adanya unsur tenaga, ruang, dan tempo atau waktu. Seni tari untuk PAUD merupakan seni yang menekankan pada gerak, keharmonisan gerak, mengontrol gerak motorik kasar maupun motorik halus yang dapat mengembangkan kecerdasan anak (Rachmi 2008). Lama waktu menari anak usia dini adalah selama 40 menit jenis tari atau karateristik tari anak usia dini adalah tari yang bertema dan tari berkelompok contohnya tari Hudoq Dayak Bahau yang merupakan tari tradisional Kalimantan Timur yang menggunakan topeng sebagai perwujudan dari binatang,leluhur dan dewa. Gerak Tari Hudoq Dayak Bahau yaitu gerakan pertama disebut jiak yang lebih menekankan gerakan kaki maju sambil menghentakkan kaki disusul oleh tumit, gerakan kedua yaitu gerakan kombinasi kaki dan tangan berulang - ulang dan berayun -ayun ke atas lalu kebawah, gerakan ketiga atau akhir yaitu gerakan tangan yang menggelantung mengikuti gerakan arah badan. Berdasarkan penelitian diatas bahwa Tari hudoq dayak bahau menjadi tarian yang mampu meningkatkan kecerdasan kinestetik anak sebesar 97,7 \% dengan melakukan penelitian Pra Siklus,Siklus I dan Siklus II di Taman Kanak-kanak Negeri Pembina 2 Muara Wahau.

\section{Kesimpulan}

Hasil analisis penelitian bahwa kegiatan melalui gerak tari hudoq dayak bahau dapat meningkatkan kecerdasan kinestetik anak, dan dapat melatih anak berkonsentrasi dan perhatian lebih 
lama, memahami apa yang disampaikan oleh guru, serta dapat membantu anak saling berinteraksi secara sosial, dengan praktek langsung membuat anak mengingat pengalamannya. Hal ini dapat dilihat dari hasil analisis anak pada kelompok B pada pra siklus pertemuan I dan II mencapai nilai rata-rata $17,3 \%$ yang berkatagori belum berkembang, dan pada siklus I pertemuan I dan II 40,98\% yang berkategori berkembang, sedangkan pada siklus II meningkat yaitu mencapai rata-rata $97,7 \%$ dengan katagori berkembang sangat baik. Dari hasil tersebut dapat disimpulkan bahwa penelitian tindakan kelas ini dikatakan berhasil karena sudah melebihi kriteria penilaian yang ditentukan sebagai indikator keberhasilan yaitu $80 \%$.

\section{Daftar Pustaka}

Arbibah. 2017. Pembelajaran Tari Jepen dapat Meningkatkan Kecerdasan Kinestetik Anak .Samarinda, Fakultas Keguruan dan Ilmu Pendidikan Universitas Widya Gama Mahakam

Aqib, Zainal. 2017. Penelitian Tindakan Kelas . Yogyakarta,ArRuzz Media

Banjari, Al- Sahli. 2017. Tari Hudoq Suku Dayak Bahau . Perpustakaan Digital Indonesia (Online)

Giri,Indra. A. 2013. Memaksimalkan Kecerdasan Anak .Yogyakarta, Star Books

Herjayanti, Risna. 2014. Makna Simbolik Tari Hudoq Pada Upacara Panen Bagi Masyarakat Suku Dayak Ga'ay.Yogyakarta, Universitas Negeri Yogyakarta

Mulyani,Novi. 2016. Pendidikan Seni Tari Anak Usia Dini.Yogyakarta, Penerbit Andi

Rachmi,Tetty. 2008. Keterampilan Musik dan Tari. Ed.1.cet.II. Tanpa Kota, Universitas Terbuka 
Surya, Sutan. 2007. Melejitkan Multiple Intelligences Anak Sejak Dini. Yogyakarta, Penerbit Andi

Suyadi. 2016. Teori Pembelajaran Anak Usia Dini Dalam Kajian Neurosains.Yogyakarta, Remaja Rosdakarya

Sujiono,Yuliana Nurani. 2010. Bermain Kreatif Berbasis Kecerdasan Jamak. Jakarta, PT.Indeks 